\title{
Timing of transitional justice mechanisms and the implications for the South Sudan peace process
}

\author{
Ibrahim Sakawa Magara
}

\begin{abstract}
The South Sudan peace agreement provides for transitional justice mechanisms aimed at fostering justice and reconciliation. They include the Commission for Truth, Reconciliation and Healing (CTRH) and the Hybrid Court for South Sudan (HCSS). Drawing on qualitative data obtained from interviews, document reviews, and archival research conducted between October 2019 and June 2020 in Addis Ababa, Kampala, and Nairobi, this study delves into the current transitional justice discourses in South Sudan with a particular focus on truth-telling and accountability. The study finds that key contestations relate to when to initiate and implement transitional justice mechanisms, warning that, if not carefully timed, those mechanisms may have a negative impact on the peace process.
\end{abstract}

Keywords: South Sudan, peace, justice, reconciliation, transitional justice, truth-telling, accountability.

Note on the author: Ibrahim Sakawa Magara is a Policy Leader Fellow at the European University Institute's School of Transnational Governance and a PhD candidate at Loughborough University. Magara is particularly interested in peace and security regionalisms and the role of Africa's regional economic communities (RECs) in conflict management on the continent. He currently researches on the Intergovernmental Authority on Development (IGAD)'s peace process in South Sudan. Magara's recent publications include a chapter co-authored with Hubert Kinkoh entitled: 'China's military positioning in the horn of Africa and its implications for regional and global security outcomes', in Courting Africa: Asian Powers and the New Scramble for the Continent, (The Zambakari Advisory Special Issue, Summer 2020), and a chapter co-authored with Anne Munene entitled 'The role of social media in Africa's democratic transitions: Lessons from Burundi', in Carr, P.R., Hoechsmann, M. \& Thésée, G. (eds) (2018), Democracy 2.0: Media, Political Literacy and Critical Engagement (Leiden, Brill).

(C) The author(s) 2021. This is an open access article licensed under a

Creative Commons Attribution-NonCommercial-NoDerivs 4.0 Unported License 


\section{Introduction}

Approaching transitional justice from a peacebuilding perspective (Lambourne 2009: 29), this article assesses truth-telling and prosecutions in relation to peacebuilding in South Sudan. This article places the case of South Sudan within broader transitional justice theory and practice, accentuating the significance of the timing of truth-telling and accountability mechanisms as provided for in the Revitalised Agreement on the Resolution of the Conflict in South Sudan (R-ARCSS) (IGAD 2018).

This article draws on qualitative data obtained from extensive fieldwork that involved interviews, as well as archival research and document reviews. They include thirty-eight interviews conducted between November 2019 and June 2020 in Addis Ababa, Kampala, and Nairobi. With a purposive sampling strategy, participants were largely selected based on their involvement in the South Sudan peace process as members and/or partners of the Intergovernmental Authority on Development (IGAD), technical experts and resource persons, members of various institutions established under the R-ARCSS, representatives of parties to conflict, analysts, scholars, and civil society actors.

\section{The conflict}

Barely two years after South Sudan's independence, a deadly political crisis broke out heralded by a factional military battle (Akol 2014: 7-8). President Kiir accused his political rival, Riek Machar — whom he had sacked as Vice President—of plotting a coup, and arrested and detained thirteen political figures (Pinaud 2014: 192) triggering a bloody civil war that quickly took an ethnic dimension (Johnson 2014) claiming about 400,000 lives and displacing millions (ICG 2021: ii).

The conflict is rooted in legacies of a troubled history of a people trying to find their identity away from external ideologies of 'pan-Arabinism' and Islamism (Johnson 2016: 6-7). As argued by De Waal (2014), the civil war was rooted in a system of a violent 'political marketplace' where access to political power is based on a speededup, dollarised mode of transactional politics. At independence South Sudan 'was beset with poisonous social dynamics' (Vertin 2018: 147) exacerbated by military factionalism within Sudan People's Liberation Movement (SPLM) (Pinaud 2014: 192) and heavy militarisation (De Waal 2017). South Sudan's political elite 'appeared to have misunderstood independence as the finish' (Vertin 2018: 147) and hence failed to pay attention to historical cleavages which contributed to the civil war (ICG 2021; Jok 2011, 2014). 
Following the deadly conflict, IGAD convened an extraordinary summit marking the start of a mediation process culminating in the Agreement on the Resolution of the Conflict in the Republic of South Sudan (ARCRSS) in 2015 which collapsed a year later (Blackings 2016). IGAD embarked on another phase of a perilous mediation journey that resulted in the R-ARCSS in 2018 whose implementation has been dragging on (Onapa 2019) with the feeling of a failing peace setting in (Awolich 2020: 2). IGAD's involvement in South Sudan is anchored on its founding principle of peaceful settlement of regional conflicts (Apuuli 2015: 125) as well as the UN and AU (African Union) principle of subsidiarity (Apuuli, 2015: 22-3, Asgedom 2019: 84). With numerous ceasefire violations (Onapa 2019: 75) and the emergency of the COVID-19 pandemic (ICG 2020), the state of peace in South Sudan remains uncertain (Bereketeab 2017).

\section{Transitional justice}

The International Center for Transitional Justice (ICTJ 2009) conceptualises transitional justice as involving: a particular conception of justice; a field of policy expertise; a branch of research and law; a unique form of human rights advocacy and activism; and an academic discipline. Trials, truth commissions, amnesties, reparations, and lustration are the most common transitional justice mechanisms (Olsen et al. 2010: 805). At the core of transitional justice is the demand for justice and the need for peace (Sriram \& Pillay 2010). While justice and peace are equally important, overemphasis on either may prove detrimental to the other (Prorok 2017), posing transitional justice's greatest dilemma.

Since the Nuremberg war crimes trials (Teitel 2003), transitional justice has emerged as a 'globally recognised response to human rights violations after violent conflicts' (Bentrovato 2017: 396) with many countries employing its mechanisms (Teitel 2003: 70-2, 2015, Hayner 2010, Olsen et al. 2010: 2, Matsunaga 2016: 25). Examples are amnesties in Spain (Jimeno 2017), mixed courts in Cambodia and Sierra Leone (Stensrud 2009), truth and reconciliation in South Africa (Gibson 2006), among many others (Murphy 2017: 10). Between 1970 and 2007 there were 81 trials in 38 countries, 53 truth commissions in 37 countries, 229 amnesties in 72 countries, 23 reparations programmes in 18 countries, and 34 lustration policies in 23 countries (Olsen et al. 2010: 807).

Drawing on the cases of Cambodia, Rwanda, East Timor, and Sierra Leone, Lambourne (2009) sees transformative models of transitional justice as potentially aiding peacebuilding processes. Yet the said transformative model for peacebuilding during transition calls for an interrogation of whose justice it delivers. Lundy and 
McGovern (2008) strongly argue for a participatory approach that allows a consensual, broad-based concept of justice acceptable by those concerned. While some pundits warn against narrowing and depoliticisation of transitional justice (Nagy 2008), its broad and political nature raises challenges related to when, to whom, and for what transitional justice apply.

There are normative and practical dimensions to implementing transitional justice mechanisms (Buhm-Suk et al. 2016: 11). As argued by Teitel (2005: 1617), 'the central dilemma is how to transform a society that has been subjected to illiberal rule and the extent to which this shift is guided by conventional notions of the rule of law and the responsibility associated with established democracies'. Even the world's advanced democracies, such as the settler states of Canada, USA, Australia, and New Zealand (Winter 2014), continue to face challenges of systematic human rights violations, expanding transitional justice to include addressing harms to indigenous peoples, among others (Matsunaga 2016: 25).

Advocates of transitional justice argue that its mechanisms strengthen rather than weaken peace and democracy (Thomas et al. 2008: 11). For example, the reconciliation efficacy of truth-telling is articulated by the Sierra Leonean Truth Commission (2004: 45) when it reports that 'truth telling provided the people of Sierra Leone with a forum for private and public acts of reconciliation'. Sceptics, on the other hand, question the efficacy of transitional justice mechanisms, such as truth-telling in contributing to justice and peace (Mendeloff 2004).

On the basis of an ethnographic study in Bosnia and Herzegovina, Palmberger (2016) illustrates the complexities associated with reconstitution of shared narratives, revealing how certain mechanisms, however well meaning, may actually lead into a reproduction of painful memories. Drawing on the case of Rwanda, Brounéus (2010) presents the psychological health risks associated with truth-telling. Yet through the same gacaca mechanisms, Honeyman et al. (2004) illustrate the innovative ways through which Rwanda attempted to address its complex situation. Elsewhere, Meierhenrich (2006: 106) posits that, 'if excessive, mechanisms of postwar justice can have disastrous effects for international peace and security. They may exacerbaterather than cure - the consequences of war'. While truth commissions are deemed to have been relatively successful in situations like South Africa, they are seen to have been less successful in cases like Tunisia and Nepal (Murphy 2017). These cases show the mixed outcomes of truth-telling as a transitional justice mechanism.

Accountability through criminal prosecutions as a transitional justice mechanism reveals similar mixed outcomes. For example, Kenya's situation at the International Criminal Court (ICC) reveals the threat of accountability to stability (Dunaiski 2014). Yet there are findings from other parts of the world, such as Latin America, indicating that human rights trials do not undermine stability (Sikkink \& Walling 2007: 427). 
These scenarios reveal the complexity and uncertainty that characterise implementation of various transitional justice mechanisms, accentuating the significance of context. How transitional justice mechanisms are designed and implemented, and the context in which they are applied, contribute to further theorisation and innovative practices (Matsunaga 2016: 25). Transitional justice mechanisms can be useful or harmful depending on a number of factors, including timing. How South Sudan will structure and time its truth-telling and accountability mechanisms will go a long way in determining their success.

\section{Transitional justice mechanisms in South Sudan}

\section{Foundations of transitional justice}

Following the outbreak of the civil war, the AU Peace and Security Council (PSC) established a Commission of Inquiry on South Sudan (AUCISS) with the mandate to investigate human rights violations and propose measures for accountability, healing, and reconciliation. The AUCISS established that the conflict unearthed complex issues characterised by deep divisions and resentment within the South Sudanese society. The Commission concluded that there was a need to establish the truth, acknowledge human rights violations, and ensure justice and accountability in order to achieve healing, reconciliation, and sustainable peace (AU 2014: 275-304).

The recommendations of the AUCISS 'generated the impetus for the inclusion of transitional justice mechanisms-including the CTRH [Commission for Truth, Reconciliation and Healing] and the HCSS [Hybrid Court for South Sudan] - in the IGAD-led mediation process resulting in the drafting of Chapter 5 of the R-ARCSS' (HRC 2020: 3). The R-ARCSS (Article 5.1.3) anticipates that the CTRH and HCSS, together with other mechanisms, should be implemented in a mutually reinforcing manner to "promote the common objective of facilitating truth, reconciliation and healing, [and] compensation and reparation for gross human rights violations in South Sudan'. This recognition is important in the sense that it highlights transitional justice's perennial theoretical and practical dilemmas and challenges. This has to do with 'the tendency toward binary debates: peace versus justice, punishment versus reconciliation, retributive versus restorative justice, law versus politics, local versus international, individual versus collective' (Clark \& Palmer 2012: 4). The same dichotomisation is playing out in the discourses on transitional justice in South Sudan. 


\section{The actors}

There are multiple actors involved in South Sudan's transitional justice processes. For example, while the AU takes the lead on the HCSS, it works with many other stakeholders. The R-ARCSS - which includes transitional justice mechanisms - is a product of a broad range of actors coming together under IGAD-Plus ${ }^{1}$. There are many other stakeholders that are not part of the IGAD-Plus yet contribute significantly to and/or influence the design of transitional justice mechanisms, each playing different roles at various levels of the peace process. For example, religious groups in South Sudan and beyond have played a major role in shaping the healing and reconciliation discourse while civil society groups have taken a lead in the accountability front (Interview-SC1 23 February 2020). The Catholic Church has been particularly instrumental in facilitating a process led by the Community of Sant'Egidio (2020) engaging parties that are not signatories to the R-ARCSS in a bid to secure a buy-in especially because their non-engagement would pose a major risk to the viability of the peace process. On 8 March 2021 in Naivasha, Kenya, these efforts led to the signing of the Declaration of Recommitment to the Cessation of Hostilities Agreement of 21 December 2017, Rome Declaration on the Peace Process in South Sudan of 12 January 2020, and Rome Resolution on Monitoring and Verification of the Cessation of Hostilities Agreement of 13 February 2020 (IGAD 2021).

The parties that have been involved in the peace process, under IGAD, are many and their roles and contributions diverse. Mapping these actors and analysing their place and role in shaping South Sudan's transitional justice trajectory reveal a multifaceted and politically intricate process that is beyond the scope of the current article but which forms an entire chapter in this author's forthcoming work. The focus of the current article, therefore, is on the inception and implementation of two-CTRH and HCSS - of the transitional justice mechanisms as provided under the R-ACRSS. Departing from the assumption that there is consensus on the need to implement the $\mathrm{R}$-ARCSS, the main argument of this article is that timing is a major factor that will contribute to determining the success of the CTRH and HCSS.

\footnotetext{
${ }^{1}$ IGAD Plus Members are quite numerous; they include: Members of IGAD (Djibouti, Ethiopia, Kenya, Somalia, Sudan, Uganda); five representatives of AU (Algeria, Chad, Nigeria, Rwanda, and South Africa); the African Union Commission (AUC); the People's Republic of China; the European Union (EU); the Co-Chair of IGAD Partners Forum (Australia, Austria, Belgium, Brazil, Canada, Czech Republic, China, Denmark, Finland, France, Germany, Greece, Japan, India, Ireland, Italy, Luxembourg, The Netherlands, New Zealand, Norway, Russian Federation, Spain, Sweden, Switzerland, Turkey, United Kingdom, United States of America, European Union and the League of Arab States); and the Troika (Norway; UK and USA; and the United Nations (UN). See: https://igad.int/index. php?option $=$ com_content $\& v i e w=$ article $\&$ id $=1187$ :press-release-participation - of - the - ig ad-plus-peace-process\&catid=1:latest-news
} 


\section{Transitional justice discourses}

Discourses on transitional justice in South Sudan revolve around institutional design, historical injustices, human rights violations, truth, healing and reconciliation, reparations, and accountability (Interview-SC1 23 February 2020). These aspects fundamentally touch on the character of the SPLM and the nature of the South Sudanese state (Pinaud 2014: 193) and apparent failure to design a viable polity from its inception (Jok 2014). There are those who think that transitional justice 'should have happened way back in 2011 ... preparations for this should have been done during the 6-year transitional period provided for in the Comprehensive Peace Agreement (CPA)' (Interview-CS1 23 February 2020). Indeed, 'the CPA contained a provision for a national reconciliation process, but the government of the south did not undertake any credible initiative in this regard for fear that it could revive old grievances and jeopardise the outcome of the intended referendum on self-determination' (Oola \& Moffet n.d: 6). Arguably, had some of the transitional justice mechanisms, such as accountability, been implemented during that period, the 2013 civil war may have been averted.

The year 2011 when South Sudan attained independence may have been another lost window because transitional justice tends to be successful where and when there is strong political goodwill. In 2011 South Sudan enjoyed internal political goodwill and external support which could have benefitted certain transitional justice mechanisms. Expressing regret, a senior member of the SPLM is reported to have said: 'shame on us, shame on us: we failed to learn the lessons of those African liberation movements that have gone before us' (Vertin 2018: 96). Similar sentiments were shared by one of the former detainees during an interview (Interview-FD 04 March 2020).

Unlike in 2011 when the SPLM was more united and stronger, the R-ARCSS is being implemented with a deeply divided SPLM that has since split into numerous factions, with the largest being the Machar-led SPLM-IO, which is equally now suffering significant internal divisions (ICG 2021). The R-ARCSS has also brought onboard many other actors (Onapa 2019: 75) with more than ten armed and other political groups as signatories (Deng 2018: 3). Furthermore, there are other parties, like SPLM-Former Detainees who signed the agreement with reservations (Onapa 2019: 75-6) and yet others, like the South Sudan National Democratic Alliance (SSNDA), that declined to sign the agreement and who are now engaged in the ongoing Rome process (Community of Sant'Egidio 2020). Bringing all actors together is important for transitional justice. As one of the informants opined, 'transitional justice is about all of us, the people of South Sudan, coming together to talk about our problems and find an agreeable way out' (Interview-FD 04 March 2020). While inclusivity is vital, it equally means that it is much more difficult to create consensus on when and 
how to establish and implement transitional justice mechanisms as provided for in the R-ARCSS.

\section{Political environment}

Transitional justice mechanisms are deeply political processes whose successes or failures largely depend on the prevailing and evolving political dynamics. For South Sudan, transitional justice mechanisms are crafted into the R-ARCSS, an agreement that is itself an outcome of contentions and antagonisms between and among many actors both within and outside South Sudan (Verjee 2020).

De Waal (2015), through his 'political marketplace' concept, reveals the complexity characterising politics in South Sudan and their historical and regional dimensions. Even as this discourse on transitional justice goes on, it is worthwhile noting that political goodwill from South Sudanese political elites and their regional and global networks is fundamental. While South Sudanese leaders may publicly claim to support the establishment of the HCSS, which has since been approved (Tut Pur 2021), they do not seem to have the appetite for justice. It is curious, for instance, to note that, among those who were reached for interviews, only respondents who are not affiliated to either of the South Sudan's opposing sides, openly expressed concerns over lack of political goodwill. On their part, protagonists tend to engage in blame games. For example, those aligned to the incumbent government accuse the SPLM-IO of not being willing to participate in the national dialogue (Interview-SSGO2 06 May 2020), while those on the side of SPLM-IO posit that the dialogue was unilateral and onesided (Interview-IO 13 February 2020). Their shrewdness is even subtle on the question of accountability, although they all claim to support the establishment of the HCSS.

Acceptance and even calls for justice, from either side of the protagonists, may be more about tactical political manoeuvring than expressions of genuine desires for justice. In fact, the positions that each party takes on the matter of HCSS have been found to be quite polarising, leading to more factions within different parties. For example, a senior member of SPLM-IO questions Machar's consent to the HCSS, stating that he had 'difficulties explaining to some of our boys that we will ensure they are not locked in' (Interview-IO 13 February 2020). This may be fodder for continued insecurity since lower cadre fighters may not feel protected from impending punishment.

The UN Human Rights Council (HRC 2020: 7-8) documents how delay tactics have been employed in frustrating the process of establishing the HCSS. It has taken tremendous diplomatic efforts and strategic pressure to have the hybrid court finally approved. However, approval of the court is one thing and operationalising it is quite another. For example, there is a need to ensure that 'transitional justice is pursued as 
an integral component of peacebuilding and development in South Sudan, including by ensuring appropriate allocation of adequate resources' (HRC 2020: 25). Yet the leadership of South Sudan hides behind insufficiency of resources and prioritisation. As one of the diplomats rightly observed, 'this brings about a major dilemma particularly to external actors ... are you going to put money on more pressing basic needs like food and healthcare or on pursuing criminal justice?' (Interview-ED 05 June 2020). This has equally led to lack of coordinated efforts in supporting transitional justice processes as each actor tends to seek different pathways to make their contribution based on their own policies.

The R-ARCSS brings people who deeply mistrust each other together. South Sudanese leaders may not necessarily be establishing transitional justice mechanisms for the purpose of ensuring justice and building peace. To the contrary, they will attempt to use their positions of power to influence the transitional justice mechanisms to their advantage. Criminal prosecutions, for instance, may be weaponised to punish political opponents as opposed to delivering justice, and the truth-telling process may be manipulated to reward certain constituencies through reparations. The level of mistrust and political manoeuvring by South Sudanese political elites, under the current Revitalized Transitional Government of National Unity (R-TGoNU), arguably makes the prevailing political environment unsupportive of the proposed transitional justice mechanisms.

\section{Presentation and discussion of key findings}

\section{Truth-telling}

The main aim of the CTRH is to uncover the truth about past abuses and promote healing. It is explicitly linked to the Compensation and Reparation Authority (CRA) in terms of reparation of victims through the Compensation and Reparation Fund (CRF) (Akech 2020: 589-90). According to Article 5.4 of the R-ARCSS (IGAD 2018), the CRF will 'provide material and financial support to citizens whose property was destroyed by the conflict and help them to rebuild their livelihoods'. The CRA will also receive applications from victims recorded by the CTRH and provide them with 'appropriate compensation and reparation' (IGAD 2018). Reparation is a well-established mechanism of transitional justice that has been practised in many countries (Oola \& Moffet n.d: 4). While not the immediate focus of this article, in the mutually reinforcing design of South Sudan's transitional justice framework, reparations are closely linked to the CRTH. 
There seems to be consensus on the need for truth-telling in South Sudan. There is a recent study (Willems \& Deng 2016) indicating that 74 per cent of South Sudanese support truth-telling. A majority at 68 per cent considered such national consultations to be an important means of bringing about reconciliation while 48 per cent saw national dialogue as helpful in finding and documenting what actually happened to their loved ones. Queried on what needed to happen in promoting reconciliation, 64 per cent emphasised grass-roots level public dialogue while 57 per cent saw its importance as lying at the national level. The researchers concluded that 'this illustrates the comfort and faith people have in grass-roots level initiatives, while at the same time understanding that this cannot go without initiatives from and a political solution at the national level' (Willems \& Deng 2016: 3).

Respondents to this study were very clear about the right of the people of South Sudan, particularly the victims, to know the truth. For example, a South Sudanese civil society representative opined that 'for many victims to have closure, they need to know what exactly happened, for example, people need to know who killed their loved ones, when, how and why' (Interview-SC1 23 February 2020). Whether these are demands for the right to truth or mere vocalisation of the benefits of narrating the truth is difficult to ascertain immediately. This is because this study's informants were largely elites whose responses may not represent what the vast majority of South Sudanese actually mean by the right to truth. Even the study cited above may not fully answer this question because it is based on a survey. To get into the depths of what the right to truth may exactly mean for ordinary South Sudanese, especially victims, may require more in-depth engagements, for example, through ethnographic studies. In this article, the right to truth is viewed through the lens of the significance that the people of South Sudan attach to the establishment of a clear record of what exactly happened and how it happened. According to the mutually reinforcing designs of transitional justice mechanisms in South Sudan, the revealed truth should lead to and/or inform other actions, including reparations and accountability.

The healing value of truth-telling is not dominant in current discourse on transitional justice in South Sudan. It is a marginal narrative largely domiciled within sections of religious circles. What is vivid is a view of truth-telling as an acknowledgement of wrongs and as a form of recognition and restoration of dignity to the victims (AU 2014). There is literature that argues in support of these claims. For example, Biggar (2003: 8) opines that 'truth-telling entails recognition of injuries hence acknowledging the dignity of the direct victims'.

The need for truth-telling comes across as one of the few aspects acceptable across the board as representatives both from the incumbent government (Interview-SSGO1 12 March 2020) and the opposition (Interview-IO 13 February 2020) generally agree on the need for the people of South Sudan to know what exactly happened. However, as 
Owiso (2019) observes, seeking the 'truth' after a devastating, multilayered, and complex conflict is such a daunting task. Furthermore, those responsible for this process need to pay attention to the fact that management of the truth is an equally complicated undertaking. For example, the case of Rwanda reveals how experiences of truth-telling may result in re-traumatisation (Brounéus 2010). Furthermore, as illustrated through the case of northern Uganda, normatively driven transitional justice mechanisms within a liberal peace framework may have little bearing on lived realities of social accountability in post-conflict settings (Macdonald 2017).

It is therefore important to guard against ills such as a reproduction of problematic liberal peace archetypes of peace through truth-telling mechanisms. Imposing timelines and external interference are some of the factors that may jeopardise the efficacy of truth-telling. The following section uses the experiences of the recently concluded South Sudan National Dialogue (SSND) to illustrate some of the challenges that may be expected and lessons for the proposed truth-telling under the CRTH.

\section{South Sudan National Dialogue (SSND): lessons for the CRTH}

This section examines and presents various discourses on the SSND: mainly its challenges and their implications for the CTRH. This is particularly because the proposed truth-telling process under the CTRH emphasises addressing legacies of the conflict, promotion of peace, national reconciliation, and healing (IGAD 2018), objectives similar to those of the SSND (Deng 2017: 17). The major difference between the SSND and the CTRH is that the former was initiated prior to the signing of the R-ARCSS while the latter is part of and an outcome of the agreement. However, given the fact that the SSND dragged on to late 2020, way into the implementation of the peace deal, and the fact that the political terrain in the country has not changed significantly, it is plausible to think of similar and/or related challenges recurring during the CTRH process.

\section{The SSND and its achievements}

The SSND was initiated by President Kiir in December 2016, ostensibly with the intention of collecting the views of the people of South Sudan on how to resolve the conflict and foster healing and reconciliation (HRC 2020: 7). The structural framework that was put in place to facilitate the SSND included the 9-member national leadership, a 97-member steering committee (NDSC), the Secretariat, and the stakeholder and partner forums (Vhumbunu 2018). The composition of the 15 subcommittees for regional and grass-roots consultations was by personal choice of the members of the Steering Committee. This means members were free to decide 
which regional subcommittee to join so long as each of the committees did not exceed five members (Deng 2017: 70). Multifaceted in the nature of issues to be tackled, the SSND was expected to be broad based and comprehensive with the aim to 'promote peace, national unity, equitable socio-economic development, and a shared sense of national purpose' (Deng 2017: 18).

Generally, 'there were mixed reactions since some people thought it was a noble and indeed timely initiative, and others pessimistically feared that it would not amount to much' (Deng 2017: 69). Nevertheless, the SSND conducted hearings, and gathered and analysed information from both within and outside South Sudan in preparation for a national conference that was scheduled to take place in March 2020. The conference was postponed first due to the business of the President and later due to COVID-19 pandemic (HRC 2020:10). The SSND finally held the national conference on 3-15 November 2020 in which President Kiir was represented by Vice President Hussein Abdelbagi (SSND 2020) and concluded its work by publishing a report. Most of the issues contained in the SSND final report are well documented in other relevant documents. Noteworthy is that the report clearly indicates that 'the people of South Sudan at the grass roots are deeply aware of the leadership failure and the political deadlock which has dogged this country for a long time. So, they demand that both President Kiir and Dr. Riek Machar must leave politics, if South Sudan is to ever move forward' (Sudans Post 17 December 2020: 32).

The fate of the outcomes of the SSND is unknown. However, the fact that it recommends the stepping down of Kiir and Machar, the main protagonists in the South Sudan conflict, means that the report may never be implemented under the duo's leadership. This may be the case should either of the two become President following the expiry of the mandate of the R-TGoNU. Certainly, it is difficult for leaders to follow up on initiatives whose recommendations negatively implicate them. In Kenya, for example, it is believed that part of the reason the government has never implemented the recommendations of the 2013 Truth, Justice and Reconciliation Commission (TJTC) $)^{2}$ is because it implicates people in power, including President Kenyatta's family.

Against the general feeling that the SSND did not amount to much, those in government argue that it was a success. For instance, one of those reached for an interview opined that 'the national dialogue has been a great success ... has helped diffuse the violence and foster reconciliation' (Interview-SSGO1 12 March 2020). Interestingly, another government official, who equally applauds the success of the national dialogue, calls on the 'international community and friends of South Sudan to

${ }^{2}$ Seattle University School of Law has collected and published all the TJRC documents including all four volumes of the final report. See: https://digitalcommons.law.seattleu.edu/tjrc/ 
support the CTRH with resources and capacity' arguing that 'government alone cannot manage the tasks of CTRH' (Interview-SSGO2 06 May 2020). The question that then arises is how the country could have conducted - successfully so - the national dialogue but cannot afford to carry out a truth-telling process, given that the spirit, structure, and operation of the two are strikingly similar.

\section{Challenges of the of the SSND}

The timing and manner in which the SSND was established created considerable concern, leading to its rejection by some South Sudanese stakeholders, notably the opposition. It occurred through a presidential decree, while South Sudan was still in conflict, causing profound cynicism among many South Sudanese (HRC 2020: 10). The SSND suffered lack of inclusion, lack of a conducive environment, mistrust and misperceptions by some stakeholders, poorly attended consultation forums, shortage of resources, and fear (Vhumbunu 2018, 31-2). Furthermore, rampant insecurity and poor transport and communication infrastructure and other logistical nightmares significantly limited its operations.

The opposition boycotted the dialogue by claiming it was unilateral and partial (Interview-FD 04 March 2020) with one dismissing it as 'Salva's meaningless project' (Interview-IO 13 February 2020). This dealt a major blow to the process. As argued by Paffenholz et al. (2017: 53-72), national elites are key determinants of the successes of such dialogues. Non-participation of the opposition leaders significantly compromised the SSND's legitimacy and credibility.

\section{Implications for the CTRH}

Drawing on some seventeen cases from around the world, Paffenhholz et al. (2017: 53-72) have particularly singled out inclusivity as a major factor determining the success of national dialogues. Another factor is political goodwill and international support, both of which were hardly present in South Sudan. This article argues that architects of the CTRH need to pay specific attention to these and related challenges and learn from such experiences for the benefit of the envisaged truth-telling process.

As indicated above, the timing of the SSND was one of the reasons for the challenges the initiative faced. This is something that directly concerns the commencement of truth-telling under the CTRH. There is a feeling that the three-year transitional period may not be sufficient to conduct robust truth-telling in South Sudan. A Sudanese diplomat was particularly unequivocal about the insufficiency of time when he stated that 'it does not seem feasible that meaningful truth-telling can take place within the next three years. ... I don't think people are even ready to genuinely engage in 
this important process.' He further added that 'it would be absurd to do it as a formality ... to tick the boxes on the tasks spelled out by the agreement' (Interview-SD 14 December 2019).

The foregoing concerns over the timing of truth-telling in South Sudan are important. For example, it is important to pay attention to claims that 'there is no sufficient infrastructure, resources or capacity to facilitate the work of the CTRH' (Interview-SD 14 December 2019) or that 'government alone cannot manage the tasks of CTRH' (Interview-SSGO2 06 May 2020). Experiences of the SSND and the prevailing political environment render 'when' to constitute the CTRH and/or commence the truth-telling process an open, yet extremely important, question as far as South Sudan's transitional justice process is concerned.

\section{Accountability — the Hybrid Court for South Sudan (HCSS)}

South Sudan has approved the establishment of the HCSS (Tut Pur 2021) ushering in a new phase in the accountability discourse. Besides a view of forgiveness and reconciliation as a viable path to peace (Interview-RL 19 November 2019), studies reveal that a majority of respondents, 79 per cent, want those responsible for abuses tried before a court (Willems \& Deng 2016: 2).

The mandate of the HCSS is 'to investigate, and where necessary, prosecute individuals bearing responsibility for violations of international law and/or applicable South Sudanese laws, committed from 15th December 2013 to the end of the transitional period'. By stating that 'no immunity from serious crimes shall be permissible' (Akech 2020: 589), the R-ARCSS underscores the demand for justice that under the HCSS is international in its orientation.

\section{International justice}

The justification for internationalisation of justice relates to the nature of the crimes that victimise humanity, and trigger internationalised insecurities and humanitarian crises and insufficiencies of domestic institutions (Drumbl 2007: 6-7). As observed by Owiso (2019: 2), 'violations committed during violent conflict generally fall within the purview of international human rights law and international humanitarian law'. Yet international justice is heavily contested (Krcmaric 2018, Akech 2020: 587-9) largely due its perceived vulnerability to external interference.

The R-ARCSS stipulates that the HCSS should operate outside the structures of the national judiciary and assume primacy over national courts. It further provides that '[the] majority of the judges shall be drawn from African countries other than 
South Sudan and that the hybrid court's structure, seat and composition are to be decided by the AUC' (Akech 2020: 587). Furthermore, external actors, like the EU (Sudan Tribune 16 November 2015), the UN (Voice of America 12 March 2019), and Western nations (The East African 13 0ctober 2018) are outspoken in their support for the HCSS, making it a highly contested topic both in and outside South Sudan.

\section{Contestations of international justice}

In his classic work Huntington (1991: 228) warns that 'prosecutions could destroy the necessary basis for democracy'. Bringing in the notion of timing, he argued that, if they should be conducted at all, then trials ought to be conducted immediately after the transition. As recounted by Sikkink and Walling (2007: 428), 'many actors directly involved in transitions were often equally pessimistic'. For example, they cite Jose Zalaquett (1990), a Chilean human rights lawyer, who argued for the inadequacies of trials to 'deal with perpetrators who still wield considerable power'.

Africa and the International Criminal Court (ICC) have featured prominently in recent discourses on international criminal justice (Sunga 2014, Benyera 2018, Chipaike et al. 2019). The ICC-Africa question is complex and perforated with controversies. These include claims that the ICC is selectively targeting and/or using Africa as a laboratory or a scapegoat, or that in its quest to achieve legitimacy and credibility the ICC had to begin with the weakest and not necessarily the most criminal elements (Imoedemhe 2015: 82-5). The fact that the ICC is based in the West with most of those standing trial being Africans has seen the debate on the court take an Africa vs the West stance. Differences on foundational philosophies and normative commitments are, in part, causes for the visible friction between the West and Africa when it comes to international criminal justice.

The ICC question is significant to the HCSS given that some of IGAD member states (Kenya and Sudan) that negotiated the South Sudan peace agreement have been at the centre of the Africa ICC tussle. In the case of South Sudan, opinion is divided between those who propose international mechanisms and those who argue in favour of local ones. The debate tends to create a dichotomy that (re)produces the West vs Africa binarism. The implication is that actors from the West agitate for international mechanisms of justice because they have faith in such mechanisms and/or lack faith in local ones, while African leaders propose local mechanisms because they can manipulate them (Interview-ED 05 June 2020). Hybridity emerged out of these debates, yet hybrid mechanisms are equally contentious. 


\section{The hybrid option}

Hybrid justice mechanisms are generally known to divide judicial responsibilities between the UN, or its entities, and/or other regional bodies and the concerned state. Among many other places, those models have been tried in East Timor, Kosovo, and Sierra Leone (Dickinson 2003). Some experts see 'hybrid' courts as a better model, with Sierra Leone and Cambodia presented as remedial to the challenges of the Rwandan and Yugoslavian tribunals, which were seen as distant, bureaucratic, and expensive (Stensrud 2009: 7).

Although these traditions are not incommensurable with Western systems, and share points of commonality, they differ in significant ways, including when it comes to rationales for and modalities of punishment (Drumbl 2007). While hybridity may be seen as, among other things, a way to bridge the Africa vs the West dichotomy, discourse on the HCSS appear to reproduce the said friction between local and international conceptions and approaches to criminal justice.

\section{The HCSS question}

There are those who feel that the push for accountability in South Sudan through the HCSS runs the risk of being hijacked by international actors for foreign interests (Interview-SSA 05 May 2020, Interview-FD 04 March 2020). Others think that internationalised criminal justice processes are too expensive yet achieve so little. For example, a South Sudanese religious leader argues that 'at times you wonder why we have to agitate for processes that require so much money and take too long just to try one individual whose conviction does not even seem to mean anything to the victims' (Interview-RL 19 November 2019).

There are documented findings, for instance, from northern Uganda, that reveal similar sentiments, including among victims of atrocities of the Lord's Resistance Army (LRA) (Apuuli 2011). The feeling that international justice is distant (Clark, 2018 ) is partly used as a justification for alternative local and even hybrid mechanisms (Zenati 2019). A Ugandan academic (Interview-MP 23 January 2020) sees hybrid mechanisms as outcomes of the opposition to internationalisation of justice and increasing disapproval of perceived Western imposition of justice on local situations. However, he argues that 'to the extent that those hybrid courts are largely designed and almost entirely funded by international organisations and Western nations, one cannot exactly view them as local.

As Akech (2020: 588) contends, 'including the HCSS was a response to growing pressure from international and regional actors ... the South Sudanese political leadership is inclined to reconciliation'. One of the diplomats (Interview-UNO 
03 March 2020) at the UN office in Addis Ababa, argued that: 'nobody should be cheated that these people [South Sudanese leaders] are not afraid of the hybrid court. They are scared. They may be speaking in support of the court in public but privately they are lobbying against it.' Indeed, there have been reports, in the past, of government of South Sudan hiring an American firm to lobby against the establishment of the hybrid court (Reuters 2019). This reveals the tensions underlying the establishment of the HCSS, its approval notwithstanding.

One of the South Sudanese former detainees (Interview-FD 04 March 2020) expressed his disappointment in the inclusion of the hybrid court in the peace deal calling it a 'landmine on the peace implementation path'. He wondered 'how do we start putting in place systems to punish the same people who are in the leadership that will implement the peace agreement?' Another interlocutor opined that: 'given the prevailing situation, I would hesitate to push for the prosecution of anybody in South Sudan at the moment' (Interview-UFA 29 January 2020). Commenting on the same, a Sudanese diplomat (Interview-SD 14 December 2019) posited that: 'I think that if we push too much for accountability at the moment, we risk eroding the little gains that have been made in this process', adding that 'the people of South Sudan want and deserve to see justice done ... but the time might not be the best'.

Given the polarisation that has been caused by the conflict, it is curious that these views appear to be shared across the political divide. For example, a South Sudanese diplomat in Addis Ababa (Interview-SSGO1 12 March 2020) held that 'government is not opposed to accountability mechanisms ... our concern is that if not done very well, it may cause problems to peace ... all we want is peace now ... everyone wants peace'. His counterpart from SPLM-IO (Interview-IO 13 February 2020) argued that 'it does not seem right to insist on accountability at the moment. It may scare away some people or make them start working in bad faith which will kill the spirit of the agreement.' But he was quick to add that, SPLM-IO is not scared of accountability stating that 'after all, everybody knows who committed atrocities and violated every international law'. Probed on whom he was referring to; he quickly said: 'of course it is Salva [President Kiir]'. Therein lies another danger to accountability. There is a level of confidence, in the opposition circles, that if prosecutions were to happen, then President Kiir must be one of the 'big fish to fry'. For example, Machar is alleged to have 'inflated the ffacts about initial massacres in Juba ... and made accountability his rallying cry' (Vertin 2018: 267) to paint Kiir as the perpetrator.

The view, prevalent among South Sudan's opposition groups that President Kiir should be one of those to be prosecuted may be damaging, especially if he ends up not being prosecuted and/or found guilty. There are some lessons from Kenya's situation at the ICC where some of those, like the current Deputy President William Ruto, who were agitating for the ICC process ended up being the 'clients' of the court. The Kenyan 
cases were to collapse later, largely due to government of Kenya's refusal to cooperate with the court. Kenya has yet to institute any mechanism to try those responsible for serious crimes committed during the 2007-8 post-election violence, largely because the people in power and their allies 'cannot fry themselves' (Brown \& Sriram 2012). The same scenario may play out in South Sudan where both Kiir and Machar, who are viewed as having committed atrocities (Interview-SC1 23 February 2020, InterviewUFA 29 January 2020, Interview-SD 14 December 2019) are in power.

There is reason to be sceptical of South Sudanese political elites' claims that they support the HCSS. South Sudanese political elites do not seem to have any appetite for justice; hence their postures appear to be largely tactical. With both Kiir and Machar in power, it is unlikely that operationalisation of the HCSS will commence soon. Most likely they will play delaying tactics to buy time in the hope that either of them will be victorious in the future and then use the criminal justice mechanism to punish the other.

\section{Implications for justice and peace}

Some of the ongoing discourses on criminal accountability in South Sudan demonstrate a level of discomfort regarding the HCSS. The question that arises is: why the rush to establish the court even with clear indications that it may not be a good idea to push for prosecutions at the moment? It is upon pausing this question that the externality dimension, already presented above, finds its strong empirical support. Observations of a Makerere University Professor (Interview-MP 23 January 2020) are in support of the view that the issue of accountability is being pushed by the international community, particularly Western powers. The inclusion of a transitional justice chapter, including the HCSS, in the R-ARCSS is curious. While it emanates from the AU's Commission of Inquiry (AU 2014), there are concerns that it was heavily driven by external actors operating within or influencing the AU's role in this process. Some interlocutors wonder how possible it is that leaders of IGAD member states-who have had huge challenges with international criminal justice and have been vocal in their opposition to the ICC - would have freely and willingly included mechanisms of international criminal accountability in South Sudan's peace agreement (Interview-FD 04 March 2020, Interview-MP 23 January 2020)

The US, which has a long-standing involvement in South Sudan (Vertin 2018), is increasingly fingered as a major foreign power apparently pushing for quick accountability and perhaps a key driving force behind the inclusion of the HCSS in the R-ARCSS. A South Sudanese academic based in Rumbek (Interview-SSA 05 May 2020) observed that: 'I think the US may be keen to see certain individuals punished. May be those who betrayed them after independence ... or even to ensure that South 
Sudan is politically organised in a way that favours its interests.' Another interlocutor (Interview-CS1 23 April 2020) argued that 'there is obviously tension between those who want to see justice and those who think that justice is not a priority at the moment'. Additionally, one other informant (Interview-FD 04 March 2020) asserted that 'it may cause more problems because of their push for quick accountability'. A diplomat from one of the European countries, argued that 'with my experience working within this context, I think that we need to be very careful with our rush'. Further, he stated that 'there is a way that we [in reference to the West] want to have things done by yesterday. This could be our way of doing things but I am afraid it isn't helping the situation much over here' (Interview-ED 05 June 2020). These voices are quite revealing of experts' views on the question of HCSS, conveying the need for caution in timing of accountability measures in South Sudan.

Other than the perceived external pressure to establish the HCSS (Akech 2020: 588), it is noteworthy that civil society in South Sudan seems to be pushing for quick prosecutions as well. For example, an informant (Interview-SC1 23 February 2020) from the sector argued that 'transitional justice is a civil society agenda ... all the mechanisms provided for in the agreement are long overdue'. His counterpart (Interview-CS2 16 April 2020) was of the view that 'justice it too important to wait. The people of South Sudan, particularly the victims, most of whom are women, have waited for far too long. They cannot wait any longer for justice. The time for justice is now.' Positioned as the voice of the people against the powerful elites as well as its well-established links to external actors (such as through donor-aid) are arguably some of the reasons for civil society's posture on this matter.

The position of civil society notwithstanding, a vast majority of those who were interviewed, are of the opinion that South Sudan is not yet ready for criminal prosecutions. Many of them are concerned that a push for quick accountability may undermine the fragile peace process. Putting this into perspective, a South Sudanese Lawyer (Interview-SSL 21 May 2020), based in Juba, asserted that 'perceptions on the hybrid court are divided ... as expected there are those who feel that this is a foreign agenda and those who argue that instead of the hybrid court, we should rather invest in local courts'. He maintained that 'it is always a desire to have justice done within each jurisdiction but our judicial system is too weak'. He concluded that 'the current political environment does not allow for the proper functioning of the hybrid court, but from a legal point of view, the longer you take to prosecute the more complicated those cases become due to collecting of evidence, reliability of evidence ...'. This clearly captures the dilemma at play when it comes to prosecutions under the HCSS in South Sudan. 


\section{Conclusion}

Whereas the need for truth and demands for accountability in South Sudan appears not to be in question, there are concerns over the timing of various mechanisms of transitional justice, particularly truth-telling and prosecutions. It is difficult to spell out the 'right timing' for truth-telling and accountability measures in South Sudan. While there could be an argument, for example, that, due to challenges associated with prosecutions, it would be good for South Sudan to pursue alternative mechanisms such as reconciliation and national cohesion, this article does not prescribe those alternatives as a replacement but rather as available options and possibilities that the people of South Sudan are free to explore, especially within the framework of the CTRH. Empirical evidence suggests that the people of South Sudan have shown a leaning towards the demand for justice through prosecutions of certain key perpetrators of atrocities. This article's position is, therefore, that there are specific conditions that support the success of various transitional justice mechanisms and that those conditions do not appear to exist in South Sudan at the moment. In view of this, the notion of timing in transitional justice is not to be taken in its temporal conception, but rather in relation to when such conditions become available as the most appropriate time for certain mechanisms to be implemented. Architects of various transitional justice mechanisms in South Sudan need to pay attention to the evolving context, the political mood, and the contours of the implementation of the peace agreement. Paying attention to the prevailing political conditions and in the interest of the needs of the people of South Sudan, the CTRH and HCSS need to be carefully planned and prioritised in view of the country's delicate transition out of conflict and the sustainability of peace in the long term.

\section{Acknowledgement}

This research was funded, in part, by the Peace Research Grant Program of the International Peace Research Association Foundation.

\section{References}

Akech, J.G. (2020), 'Rethinking Transitional Justice in South Sudan: Critical Perspectives on Justice and Reconciliation', International Journal of Transitional Justice, 14: 585-95. https://doi.org/10.1093/ijtj/ijaa015

Akol, Z.D. (2014, 7 December), 'Inclusivity: A Challenge to the IGAD-led South Sudanese Peace Process', Policy Briefs (The Sudd Institute). https://www.suddinstitute.org/publications/show/ inclusivity-a-challenge-to-the-igad-led-south-sudanese-peace-process [accessed 25 May 2020]. 
Apuuli, K.P. (2011), 'Peace Over Justice: The Acholi Religious Leaders Peace Initiative (ARLPI) vs. the International Criminal Court (ICC) in Northern Uganda', Studies in Ethnicity and Nationalism, 11(1): 116-29. https://doi.org/10.1111/j.1754-9469.2011.01101.x

Apuuli, K.P. (2015), 'IGAD's Mediation in the Current South Sudan Conflict: Prospects and Challenges', African Security, 8(2): 120-45. https://doi.org/10.1080/19392206.2015.1036671

Asgedom, M. (2019), 'The African Union (AU) and Intergovernmental Authority on Development (IGAD) Partnership in Peace and Security: Achievements and challenges', Journal of Citizenship and Morality, 2(1): 80-100.

AU (African Union), (2014, 15 October), 'Final Report of the African Union Commission of Inquiry on South Sudan'. https://www.peaceau.org/uploads/auciss.final.report.pdf [accessed 27 February 2021].

Awolich, A.A. (2020, 7 June), 'The Boiling Frustrations in South Sudan', Weekly Bulletin (The Sudd Institute). https://www.suddinstitute.org/assets/Publications/5edf110da7365_TheBoiling FrustrationsInSouthSudan_Full.pdf [accessed 10 July 2020].

Bentrovato, D. (2017). 'Accounting for Genocide: Transitional Justice, Mass (Re)education and the Pedagogy of Truth in Present-day Rwanda', Comparative Education, 53(3): 396-417. https://doi.org/10.1080/03050068.2017.1317997

Benyera, E. (2018), 'Is the International Criminal Court Unfairly Targeting Africa? Lessons for Latin America and the Caribbean States', Politeia, 37(1): 1-30. https://doi.org/10.25159/0256-8845/2403

Bereketeab, R. (2017), 'The Collapse of IGAD Peace Mediation in the Current South Sudan Civil War', Journal of African Foreign Affairs, 4(1/2): 67-84. https://doi.org/10.31920/2056-5658/2018/v4n1_2a4

Biggar, N. (2003), 'Making Peace or Doing Justice: Must we Choose?', in N. Biggar (ed.) Burying the Past: Making Peace and Doing Justice After Civil Conflict (Washington, DC, Georgetown University Press), 14-41.

Blackings, M.J. (2016), 'Why Peace Fails: The Case of South Sudan's Agreement on the Resolution of the Conflict in South Sudan' (Nairobi, Friedrich-Ebert-Stiftung). https://library.fes.de/pdf-files/bueros/fes-pscc/14355-20180511.pdf

Brounéus, K. (2010), 'The Trauma of Truth Telling: Effects of Witnessing in the Rwandan Gacaca Courts on Psychological Health', Journal of Conflict Resolution, 54(3): 408-37. https://doi.org/10.1177/0022002709360322

Brown, S. \& Sriram, C.L. (2012), 'The Big Fish Won't Fry Themselves: Criminal Accountability for Postelection Violence in Kenya', African Affairs, 111(443): 244-60. https://doi.org/10.1093/afraf/ads018

Buhm-Suk, B., Collins, L. \& Yuri, K. (2016), 'Transitional Justice in Post-Unification Korea: Challenges and Prospects', in R.G. Teitel \& B. Buhm-Suk (eds) Transitional Justice in Unified Korea (New York, Palgrave Macmillan), 11-34. https://doi.org/10.1007/978-1-137-53454-5_2

Chipaike, R., Tshuma, N. \& Hofisi, S. (2019), 'African Move to Withdraw from the ICC: Assessment of Issues and Implications', India Quarterly, 75(3):334-50. https://doi.org/10.1177/0974928419860918

Clark, P. (2018), Distant Justice: The Impact of the International Criminal Court on African Politics (Cambridge, Cambridge University Press). https://doi.org/10.1017/9781108576260

Clark, P, \& Palmer, N. (2012, 1 October), 'Challenging Transitional Justice: Critical Perspectives in Transitional Justice', (Brussels, Intersentia Publishing).

https://ssrn.com/abstract=2635502; http://dx.doi.org/10.2139/ssrn.2635502 [accessed 2 March 2021].

Community of Sant'Egidio (2020, 14 February), 'South Sudan, Sant'Egidio: New Progress Towards Peace'. https://www.santegidio.org/pageID/30284/langID/en/itemID/34552/South-Sudan-SantEgidio-new-progress-towards-peace.html [accessed 10 June 2020]. 
Deng, D. (2018, December), 'Compound Fractures Political Formations, Armed Groups and Regional Mediation in South Sudan', Institute for Security Studies (ISS). https://issafrica.org/research/ east-africa-report/compound-fractures-political-formations-armed-groups-and-regional-mediationin-south-sudan [accessed 2 May 2020].

Deng, F. (2017, October), 'South Sudan National Dialogue: Conceptual Reflections'. https://www.ssnationaldialogue.org/wp-content/uploads/Conceptual-Reflections-on-South-Sudan-NationalDialogue-by-Francis-Deng.pdf [accessed 7 May 2020].

De Waal, A. (2014), 'When Kleptocracy Becomes Insolvent: Brute Causes of the Civil War in South Sudan', African Affairs, 113(452): 347-69. https://doi.org/10.1093/afraf/adu028

De Waal, A. (2015), The Real Politics of the Horn of Africa: Money, War and the Business of Power (Cambridge, Polity Press).

De Waal, A. (2017), 'Peace and the Security Sector in Sudan 2002-11', African Security Review, 26: 180-98. https://doi.org/10.1080/10246029.2017.1297582

Dickinson, L.A. (2003), 'The Promise of Hybrid Courts', The American Journal of International Law, 97(2): 295-310. https://doi.org/10.2307/3100105

Drumbl, M.A. (2007), Atrocity, Punishment, and International Law (Cambridge, Cambridge University Press). https://doi.org/10.1017/CBO9780511611100

Dunaiski, M. (2014), 'Accountability vs Stability? Assessing the ICC Intervention in Kenya', (E-InternationalRelations).https://www.e-ir.info/2014/01/09/accountability-vs-stability-assessingthe-iccs-intervention-in-kenya/ [accessed 2 March 2021].

The East African (2018, 13 October), 'South Sudan Now Under Pressure to Set Up Hybrid Court'. https://www.theeastafrican.co.ke/news/ea/South-Sudan-now-under-pressure-to-set-up-hybridcourt/4552908-4804110-format-xhtml-c5nec/index.html [accessed 20 June 2020].

Gibson, J.L. (2006), 'The Contributions of Truth to Reconciliation: Lessons from South Africa', Journal of Conflict Resolution, 50(3): 409-32. https://doi.org/10.1177/0022002706287115

Hayner, P.B. (2010), Unspeakable Truths: Transitional Justice and the Challenge of Truth Commissions, 2nd edn (London, Routledge). https://doi.org/10.4324/9780203867822

Honeyman, C., Hudani, S., Tiruneh, A., Hierta, J., Chirayath, L., Iliff, A. \& Meierhenrich, J. (2004), 'Establishing Collective Norms: Potentials for Participatory Justice in Rwanda', Peace and Conflict, 10(1): 1-24. https://doi.org/10.1207/s15327949pac1001_1

HRC (UN Human Rights Council) (2020, 5 October), 'Transitional Justice and Accountability: A Roadmap for Sustainable Peace in South Sudan'. https://www.ohchr.org/EN/HRBodies/HRC/ RegularSessions/Session45/Documents/HRC_45_CRP.4.docx [accessed 5 March 2021].

Huntington, S.P. (1993), The Third Wave: Democratization in the Late Twentieth Century, vol. 4 (Norman, OK, University of Oklahoma Press).

ICG (International Crisis Group) (2020, 24 March), 'COVID-19 and Conflict: Seven Trends to Watch'. https://www.crisisgroup.org/global/sb4-covid-19-and-conflict-seven-trends-watch [accessed 27 May 2020].

ICG (International Crisis Group) (2021, 10 February), 'Toward a Viable Future for South Sudan Crisis Report No. 300'. https://www.crisisgroup.org/africa/horn-africa/south-sudan/300-toward-viablefuture-south-sudan [accessed 4 March 2020].

ICTJ (International Center for Transitional Justice) (2009), 'What is Transitional Justice?'. http://www.ictj.org/about/transitional-justice [accessed14 June 2020].

IGAD (Intergovernmental Authority on Development) (2018, September), 'Agreement on the Resolution of the Crisis in South Sudan (ARCISS)'.

https://jmecsouthsudan.org/index.php/arcss-2015/igad-hlrf-agreement [accessed 20 June 2020].

IGAD (Intergovernmental Authority on Development) (2021, 10 March), 'Parties sign Declaration of Recommitment to the Cessation of Hostilities Agreement'. https://www.igad.int/programs/ 115-south-sudan-office/2630-parties-sign-declaration-of-recommitment-to-the-cessation-of-hostilitiesagreement [accessed 10 March 2021]. 
Imoedemhe, O. (2015), 'Unpacking the Tension Between the African Union and the International Criminal Court: The Way Forward', African Journal of International and Comparative Law, 23(1): 74-105. https://doi.org/10.3366/ajicl.2015.0111

Jimeno, R. (2017), Amnesties, Pardons and Transitional Justice: Spain's Pact of Forgetting (New York, Routledge). https://doi.org/10.4324/9781315107950

Johnson, D.H. (2014), 'Briefing: The Crisis in South Sudan', African Affairs, 113(451): 300-9. https://doi.org/10.1093/afraf/adu020

Johnson, D.H. (2016), South Sudan: A New History for a New Nation (Athens, OH, Ohio University Press).

Jok, J.M. (2011), Diversity, Unity, and Nation Building in South Sudan (Washington, DC, US Institute of Peace). https://www.usip.org/sites/default/files/Diversity, \%20Unity, \%20and\%20Nation $\% 20$ Building $\% 20$ in $\% 20$ South $\% 20$ Sudan $\% 20$ (Jok).pdf

Jok, J.M. (2014, 4 January), 'South Sudan and the Prospects for Peace Amidst Violent Political Wrangling', Policy Brief (The Sudd Institute). https://www.suddinstitute.org/assets/ Publications/572b7eb49503e_SouthSudanAndTheProspectsForPeaceAmidst_Full.pdf [accessed 3 May 2020].

Krcmaric, D. (2018), 'Should I Stay or Should I Go? Leaders, Exile, and the Dilemmas of International Justice', American Journal of Political Science, 62(2): 486-98. https://doi.org/10.1111/ajps.12352

Lambourne, W. (2009), 'Transitional Justice and Peacebuilding after Mass Violence', International Journal of Transitional Justice, 3(1): 28-48. https://doi.org/10.1093/ijtj/ijn037

Lundy, P. \& McGovern, M. (2008), 'Whose Justice? Rethinking Transitional Justice From the Bottom Up', Journal of Law and Society, 35(2): 265-92. https://doi.org/10.1111/j.1467-6478.2008.00438.x

Macdonald, A. (2017), 'Transitional Justice and Political Economies of Survival in Post-conflict Northern Uganda', Development and Change, 48(2): 286-311. https://doi.org/10.1111/dech.12298

Matsunaga, J. (2016), 'Two Faces of Transitional Justice: Theorizing the Incommensurability of Transitional Justice and Decolonization in Canada', Decolonization: Indigeneity, Education \& Society, 5(1): $24-44$.

Meierhenrich, J. (2006), 'The Ethics of Lustration', Ethics \& International Affairs, 20(1): 99-120. https://doi.org/10.1111/j.1747-7093.2006.00005.x

Mendeloff, D. (2004), 'Truth-Seeking, Truth-Telling, and Postconflict Peacebuilding: Curb the Enthusiasm?', International Studies Review, 6(3): 355-80. https://doi.org/10.1111/j.1521-9488.2004.00421.x

Murphy, C. (2017), The Conceptual Foundations of Transitional Justice (London, Cambridge University Press). https://doi.org/10.1017/9781316084229

Nagy, R. (2008), 'Transitional Justice as Global Project: Critical Reflections', Third World Quarterly, 29(2): 275-89. https://doi.org/10.1080/01436590701806848

Olsen, T.D., Payne, L.A. \& Reiter, A.G. (2010), 'Transitional Justice in the World, 1970-2007: Insights from a New Dataset', Journal of Peace Research, 47(6): 803-9. https://doi.org/10.1177/0022343310382205

Onapa, S.A. (2019), 'South Sudan Power-sharing Agreement R-ARCSS: The Same Thing Expecting Different Results', African Security Review, 28(2): 75-94.

https://doi.org/10.1080/10246029.2019.1680402

Oola, S \& Moffet, L. (n.d.), 'Reparations in South Sudan: Prosects and Challenges'. https://reparations.qub.ac.uk/new-report-reparations-in-south-sudan-prospects-and-challenges/ [accessed 5 March 2021].

Owiso, O. (2019, September), 'Seeking “Truth” After Devastating, Multi-layered Conflict: The Complex Case of Transitional Justice in South Sudan', paper delivered to the Association of Human Rights Institutes (AHRI) Annual Conference held at the University of Potsdam on 5-7 September 2019. 
Paffenholz, T., Zachariassen, A. \& Helfer, C. (2017, October), 'What Makes or Breaks National Dialogues? Inclusive Peace and Transition Initiative Report (The Graduate Institute of International and Development Studies). https://www.inclusivepeace.org/sites/default/files/IPTI-Report-WhatMakes-Breaks-National-Dialogues.pdf [accessed 4 June 2020].

Palmberger, M. (2016), How Generations Remember: Conflicting Histories and Shared Memories in Postwar Bosnia and Herzegovina (London, Palgrave Macmillan).

Pinaud, C. (2014), 'South Sudan: Civil War, Predation and the Making of a Military Aristocracy', African Affairs, 113(451): 192-211. https://doi.org/10.1093/afraf/adu019

Prorok, A.K. (2017), 'The (In)compatibility of Peace and Justice? The International Criminal Court and Civil Conflict Termination', International Organization, 71(2): 213-43. https://doi.org/10.1017/S0020818317000078

Reuters (2019, 29 April), 'South Sudan Hires U.S. Lobbyists to Help Block War Crimes Court: Contract'. https://www.reuters.com/article/us-southsudan-justice/south-sudan-hires-u-s-lobbyists-to-helpblock-war-crimes-court-contract-idUSKCN1S51Z2 [accessed 7 June 2020].

Sikkink, K. \& Walling, C. B. (2007), 'The Impact of Human Rights Trials in Latin America', Journal of Peace Research, 44(4): 427-45. https://doi.org/10.1177/0022343307078953

Sriram, C.L. \& Pillay, S. (2010), Peace Versus Justice? The Dilemma of Transitional Justice in Africa (Woodbridge, James Currey).

SSND (South Sudan National Dialogue) (2020, 9 November), 'National Dialogue Conference', press release. https://www.ssnationaldialogue.info/press-release/national-dialogue-conference-goingjuba-3rd-15th-november/ [accessed 7 March 2021].

Stensrud, E.E. (2009), 'New Dilemmas in Transitional Justice: Lessons from the Mixed Courts in Sierra Leone and Cambodia', Journal of Peace Research, 46(1): 5-15. https://doi.org/10.1177/0022343308096152

Sudan Tribune (2015, 16 November), 'EU Vows to Support Hybrid Court on South Sudan'. https://www.sudantribune.com/spip.php?article57051 [accessed 23 May 2020].

Sudans Post (2020, 17 December), 'Final Report of South Sudan's National Dialogue'. https://www.sudanspost.com/final-report-of-south-sudans-national-dialogue/ [accessed 5 March 2021].

Sunga, L.S. (2014), 'Has the ICC Unfairly Targeted Africa or Has Africa Unfairly Targeted the ICC?', in T. Mariniello (ed.) The International Criminal Court in Search of its Purpose and Identity (Abingdon, Routledge), 147-73.

Teitel, R.G. (2003), 'Genealogy of Transitional Justice', Harvard Human Rights Journal, 16: 69-94.

Teitel, R.G. (2005), 'Transitional Justice: Postwar Legacies', Cardozo Law Review, 27(4): 1615-31.

Teitel, R.G. (2015), Globalizing Transitional Justice: Contemporary Essays (New York, Oxford University Press). https://doi.org/10.1093/acprof:oso/9780195394948.001.0001

Thomas, O. N., Ron, J. \& Paris, R. (2008), 'The Effects of Transitional Justice Mechanisms: A Summary of Empirical Research Findings and Implications for Analysts and Practitioners' (working paper; Ottawa, Centre for International Policy Studies).

Truth and Reconciliation Commission (2004), 'Witness to Truth: Report of the Sierra Leone Truth and Reconciliation Commission' (Accra, Graphic Packaging Limited).

http://www.sierraleonetrc.org/ [accessed 3 March 2021].

Tut Pur, N. (2021, 31 January), 'A Glimmer of Hope for South Sudan's Victims: The Government Approves War Crimes, Other Measures' (Human Rights Watch).

https://www.hrw.org/news/2021/01/31/glimmer-hope-south-sudans-victims [accessed 4 March 2021].

Verjee, A. (2020), 'How Mediators Conceive of Peace: The Case of IGAD in South Sudan, 2013-15', in S.M.H. Nouwen, L. James \& S. Srinivasan (eds) Making and Breaking Peace in Sudan and South Sudan: The Comprehensive Peace Agreement and Beyond (Oxford, Oxford University Press).

Vertin, Z. (2018), A Rope from the Sky: The Making and Unmaking of the World's Newest State (Stroud, Amberley Publishing). 
Vhumbunu, H.C. (2018), 'The National Dialogue Initiative in South Sudan: Assessing Progress and Pitfalls', Conflict Trends (African Centre for Constructive Resolution of Disputes), 1: 27-34.

Voice of America, (2019, 12 March), 'UN Investigators Propose Hybrid Court for South Sudan'. https://www.voanews.com/africa/un-investigators-propose-hybrid-court-south-sudan [accessed 28 May 2020].

Willems, R. \& Deng, D.K. (2016, September), 'Perceptions of Transitional Justice in South Sudan'. https://www.paxforpeace.nl/media/files/perceptions-of-transitional-justice-in-south-sudan--final-report.pdf [accessed 27 May 2020].

Winter, S. (2014), Transitional Justice in Established Democracies: A Political Theory (Basingstoke, Palgrave Macmillan). https://doi.org/10.1057/9781137316196

Zalaquett, J. (1990), 'Confronting Human Rights Violations Committed by Former Governments: Applicable Principles and Political Constraints', Hamline Law Review, 13: 623-60.

Zenati, R. (2019), 'Distant Justice and Ineffectiveness of the International Criminal Court: A Role for Hybrid Tribunals?', thesis (Leiden University Repository).

https://studenttheses.universiteitleiden.nl/handle/1887/77781 [accessed 22 April 2021].

\section{Interviews}

Personal Interview with a European Diplomat (ED) held in Nairobi on 5 June 2020

Personal Interview with a South Sudanese Lawyer (SSL) held virtually on 21 May 2020

Personal Interview with South Sudan Government Official (SSGO2) held virtually on 6 May 2020

Personal Interview with a South Sudanese Academic (SSA) held virtually on 5 May 2020

Personal Interview with a Civil Society Actor (CS2) held virtually on 16 April 2020

Personal Interview with South Sudan Government Official (SSGO1) held in Addis Ababa on 12 March 2020

Personal Interview with a member of Sudanese Former Detainees (FDs) held in Addis Ababa on 4 March 2020

Personal Interview with a United Nations Official (UNO) held in Addis Ababa on 3 March 2020

Personal Interview with a South Sudanese Civil Society Activist (CS1) held virtually on 23 February 2020

Personal Interview with Sudan People's Liberation Movement in Opposition (IO) held in Nairobi on 13 February 2020

Personal Interview with a Diplomat at Uganda Foreign Affairs (UFA) held in Kampala on 29 January 2020

Personal Interview with a Makerere Professor (MP) held in Kampala on 23 January 2020

Personal Interview with Sudanese Diplomat (SD) held in Nairobi on 14 December 2019

Personal Interview with a South Sudan Religious Leader (RL) held in Nairobi on 19 November 2019

To cite the article: Ibrahim Sakawa Magara (2021), 'Timing of transitional justice mechanisms and the implications for the South Sudan peace process', Journal of the British Academy, 9(s2): 9-33.

DOI https://doi.org/10.5871/jba/009s2.009

Journal of the British Academy (ISSN 2052-7217) is published by

The British Academy, 10-11 Carlton House Terrace, London, SW1Y 5AH

www.thebritishacademy.ac.uk 
